\title{
Brasiliens overraskende protestbølge
}

\section{Steen Fryba Christensen}

\section{Bølgen af protester, der rullede over Brasilien i juni måned, kom som en stor overraskelse for de fleste - også for den brasilianske præsident Dilma Rousseff selv}

Regeringens popularitetstal havde været meget høje i meningsmålingerne så sent som i den første uge af juni måned. Så, hvorfor startede protesterne i Brasilien og blev til en landsomfattende protestbølge i løbet af juni måned? Hvad ville demonstranterne opnå? Hvem var de? Hvad vil protestbølgen føre til?

Grunden til at bølgen af protester kom som en stor overraskelse for de fleste er, at Brasilien i løbet af de sidste ti år har oplevet en særdeles positiv udvikling på en lang række områder. I en rapport fra FN's Udviklingsprogram fra i år om den globale sociale udvikling fremhæves Brasilien ligefrem som et eksempel på et land, hvor regeringens udviklingsstrategi med stor succes har promoveret social integration og samfundets sammenhængskraft. En lang række af positive udviklinger ligger bag den tilsyneladende succes. Brasilien har haft en pæn økonomisk vækst, der sammen med en aktiv social- og erhvervspolitik har ført til rekordlave arbejdsløshedstal og et stort dyk i den sociale ulighed og fattigdom.

Historisk set har Brasilien været et land med en afgrundsdyb social ulighed. Den ekstreme fattigdom er imidlertid faldet fra 17,2 pct. til 6,1 pct. i Brasilien mellem 1990 og 2009, mens uligheden især under regeringerne ledet af Arbejderpartiet PT (2003-2013) er blevet systematisk reduceret; både mellem den højeste og den laveste indkomstgruppe, mellem rige og fattige regioner, mellem kvinder og mænd og mellem folk af forskellig race. Den positive økonomiske udvikling har ført til, at 40 millioner mennesker i et land på knap 200 millioner indbyg- 
gere er rykket op i middelklassen. Dette er sket i en kontekst af politisk og makroøkonomisk stabilitet.

Brasilien kom endog meget nådigt igennem den internationale finanskrise, der brød ud i 2008, og har trods finanskrisen været i stand til gradvist at nedbringe arbejdsløsheden, der nåede ned på omtrent 5 pct. i 2012 fra et niveau på 11-12 pct. i 2002.

Endvidere fremhæues Brasilien i en nylig PISA-undersøgelse som et af fire lande, der har opnået særligt store fremskridt inden for kvaliteten i uddannelsessystemet om end fra et lavt udgangspunkt.

Samtidig med disse usædvanligt positive økonomiske og sociale udviklinger bliver Brasilien i en international sammenhæng set som et land, der i løbet af de sidste ti år har opnået stadig større indflydelse på den internationale politiske scene via dets samarbejde med de øvrige BRICS-lande, altså Rusland, Indien, Kina og Sydafrika og som en slags uformel leder af Sydamerika.

\section{Krakeleret glansbillede?}

Denne opremsning af positive resultater for Brasilien under Arbejderpartiets ledelse kunne fortsættes, men pointen er naturligvis, at Brasilien kan beskrives som et land, der har opnået imponerende succesfulde resultater på en bred vifte af områder i løbet af de sidste 10 år. Det er derfor ikke underligt, at den sto- re protestbølge i juni måned kom som en stor overraskelse for de fleste politiske observatører og for regeringen selv. Måske var alt alligevel ikke godt i Brasilien?

Glansbilledet krakelerede og viste en situation, hvor regeringen tilsyneladende var ude af takt med den fremherskende offentlige mening, eller, i det mindste, hvor store grupper fandt grund til at protestere i gaderne i flere uger.

Hvad ville de protesterende? Hvem var de? Hvorfor opstod protestbølgen netop nu, hvor Brasilien tilsyneladende havde oplevet en usædvanligt succesrig udviklingsproces inden for mange dimensioner? Forvirringen var stor, og Arbejderpartiet, gik nærmest i panik. Protesterne gik i den grad imod partiets selvforståelse og var naturligvis yderst ubelejligt ét år før det kommende præsidentvalg.

I 2014 skal Brasilien desuden stå som vært for VM i fodbold, ligesom Brasilien er vært for OL i 2016, og det ser selvfølgelig heller ikke godt ud i den sammenhæng, at der hersker udbredt utilfredshed i befolkningen med tingenes tilstand.

Desuden kunne regeringen frygte, at protesterne, hvis de fortsætter, vil have den effekt, at de forventede resultater af at være vært for VM i fodbold og for OL i form af øget tiltrækning af turisme og af udenlandske investeringer vil udeblive.

Brasiliens tidligere præsident 'Lula' (2003-2010) havde ligefrem i 
sin tale efter den Olympiske Komités offentliggørelse i 2009 af nyheden om Brasiliens OL-værtsskab i 2016 erklæret, at dette ville betyde Brasiliens anden uafhængighed. Den politiske uafhængighed var blevet opnået med uafhængigheden fra Portugal i det 19 århundrede, og nu ville OL værtsskabet bidrage til landets økonomiske uafhængighed.

I det følgende diskuterer jeg derfor baggrunden for de folkelige protester, der brød ud i juni og forsøger at vurdere, hvad det sandsynlige udfald på protesterne vil være både $\mathrm{i}$ forhold til Brasiliens politiske og $\varnothing$ konomiske udvikling.

\section{Ikke et 'Brasiliansk Forår'}

Hvorfor opstod protesterne, hvem var demonstranterne og hvad ville de opnå? Svaret på disse spørgsmål er afgørende for at kunne vurdere, hvilket udfald regeringens svar på protestbølgen kan forventes at bringe. Skal vi forvente os folkelige protester igen under VM i fodbold i 2014, og vil dette få negative konsekvenser for den ellers ret succesrige $\varnothing$ konomiske udvikling?

Før jeg går ind i diskussionen af disse spørgsmål, er det dog vigtigt at fastslå, at demonstrationerne i Brasilien ikke var udtryk for et forsøg på at få afsat regeringen og præsidenten.

Hvis vi for eksempel sammenligner med den politiske udvikling $\mathrm{i}$ Egypten siden 2010, står det klart, at der trods ligheder i protestformer mellem Ægypten og Brasilien og trods utilfredshed med det politiske system i begge lande, er store forskelle de to lande imellem. Det er, som Marie Kolling har pointeret i en analyse af de politiske protester i Brasilien fra juli i år, misvisende at tale om et 'Brasiliansk Forår' på lige fod med det såkaldte 'Arabiske Forår'.

I processen omkring det 'Arabiske Forår' var et centralt formål for demonstranterne at få væltet autoritære regimer. Dette er ikke tilfældet i Brasilien, der har et stabilt demokratisk system, som dog kan kritiseres på en række punkter.

Endvidere er det interessant at notere sig, at til trods for et skarpt fald i den brasilianske regerings popularitet under protesterne i juni måned så var der stadig 73 pct. af de adspurgte i en meningsmåling fortaget af Datafolha under protestbølgen, der betegnede denne som god eller ok, mens kun 25 pct. betegnede den som elendig.

Samtidig var der efter alt at dømme en bred folkelig opbakning bag protesterne, der dog fortrinsvist var et by-fænomen domineret af unge fra den voksende middelklasse, der protesterede over defekter i det sociale system og i det politiske system samt over udbredt korruption og straffrihed for den politiske klasse med mere.

Meningsmålingen foretaget under protesterne i juni måned var væsent- 
ligt dårligere for regeringen end de tidligere, men var dog som nævnt ikke stærkt negativ. Desuden er regeringens popularitet steget efter denne måling og lå en uge inde $\mathrm{i}$ august på 78 pct., der beskrev regeringen som god eller ok.

Ud over at der ikke var tale om et forsøg på at vælte regeringen, giver disse meningsmålinger derfor en indikation af, at målsætningen for de protesterende måske ikke ligefrem var en dyb og revolutionerende samfundsreform, men nærmere en række sociale og politiske reformer samt en hårdere linje over for korruption. Samtidig kan protestbølgen ses som udtryk for en politisk vækkelse i den brasilianske befolkning, ikke mindst blandt den voksende middelklasse, og som et skridt i den rigtige retning i den demokratiseringsproces, Brasilien har været igennem siden protestbevægelsen, der først i 1980'erne krævede diktaturets afvikling under sloganet 'rettigheder nu'. Protesterne i starten af 1980'erne bidrog til militærdiktaturets endeligt og indførelse af demokrati.

\section{Ingen klare tolkninger}

Det er imidlertid ikke enkelt at udlægge og fortolke protesterne og deres formål. Fortolkningerne varierer, og det er vanskeligt at give et klart og entydigt bud på, hvordan protestbevægelsen skal forstås, ligesom det heller ikke er klart, om der er tale om én protestbevægelse eller om der nærmere er flere tendenser og dagsordener blandt de protesterende.

Dette skyldes bl.a., at protestbølgen opstod spontant og var karakteriseret ved et fravær af en klar ledelse. Protesterne blev først og fremmest aftalt og organiseret via facebook, hvor forskellige grupperinger har opfordret til, at folk skulle komme ud på gaden for at protestere på et givet sted og tidspunkt. Denne form for protestbølger har været ret udbredt i verden efter udbruddet af den internationale finanskrise i 2008.

Man kan argumentere for, at alle eksemplerne er relateret til den internationale finanskrise, og at de deler andre fællestræk. Der er dog også klare forskelle på baggrunden for protesterne, hvis man sammenligner de brasilianske protester med protesterne i det 'Arabiske Forår' og protesterne i vestlige lande som USA og Spanien. I det 'Arabiske Forår' var modstanden mod autoritære styrer et væsentligt aspekt, mens protesterne i Spanien (los indignados) og USA (Occupy Wall Street) opstod på baggrund af den økonomiske krise og regeringernes håndtering af denne.

Disse motivationer spillede ikke en central rolle i Brasilien, selvom nogle analytikere peger på den aftagende økonomiske vækst og den stigende inflation i Brasilien som en væsentlig faktor. Så, hvad gik prote- 
sterne ud på i Brasilien? Hvem var de protesterende? Hvad ville de opnå? Hvorfor opstod protesterne i juni 2013 i et land, der har et stabilt demokrati og har oplevet en lang social og økonomisk optur?

For at tilnærme sig en forståelse af baggrunden for protestbevægelsen i Brasilien giver det god mening først at tegne en tidslinje af udviklingen $i$ protesterne i Brasilien efter udbruddet af udbredte protester midt i juni måned 2013.

\section{Protestbevægelsens opståen}

Forhistorien for udbruddet af protestbevægelsen i Brasilien kan spores tilbage til den sociale bevægelse Movimento Passe Livre's (MPL) demonstrationer mod en stigning i prisen på busbilletter i Brasiliens største by São Paulo fra 3.00 Reais til 3.20 Reais. Der var altså tale om en stigning i prisen på busbilletter på omtrent 7 pct. svarende til ca. 50 øre.

Prisstigningen blev gennemført af det private busselskab, der står for bustransport i São Paulo, med accept fra byens borgmester fra Arbejderpartiet, Fernando Haddad, under hvis kompetence den lokale transport ligger. MPL blev dannet $\mathrm{i}$ 2005 og har som målsætning at sikre borgerne i de mange brasilianske storbyer retten til gratis offentlig transport.

Det var dog ikke oplagt, at demonstrationerne mod den annoncerede prisstigning i prisen på busbilletter i São Paulo, der startede den 10. juni, ville føre til en bred protestbølge. São Paulo har et aktivt civilsamfund med sociale bevægelser inden for en lang række enkeltsager, men det er ikke almindeligt, at demonstrationer, som den MPL gennemførte i juni, fører til masseprotester.

Desuden er masseprotester yderst sjældne fra en historisk betragtning i Brasilien. Den sidste store protestbevægelse opstod i 1992 og havde som formål at vælte den upopulære og korrupte præsident, Fernando Collor de Melo. Forud for denne havde Brasilien oplevet store demonstrationer og protestbølger i perioden op til militærkuppet i marts 1964 og udbredte protester sidst i 1970'erne og først i 1980'erne i perioden op til genindførslen af demokrati.

Dråben, der fik bægeret til at flyde over, var mediernes og politikernes reaktion på demonstrationerne mod de forhøjede priser på busbilletter. Guvernøren for delstaten São Paulo, Gerardo Alckmin, fra PSDB, det brasilianske socialdemokratiske parti, der er det vigtigste oppositionsparti til den PT-ledede koalitionsregering, kaldte demonstranterne for bøller og uromagere i lighed med de førende medier. De førende medier anses for at være konservative og på oppositionens side.

Guvernøren og de førende medier gav således udtryk for, at demonstrationerne ikke var et legitimt ind- 
spark i den politiske proces. Det var dermed med guvernørens bifald, at militærpolitiet greb til en hårdhændet behandling af demonstranterne bl.a. med anvendelse af tåregas den 13. juni på demonstrationernes fjerdedag, til trods for at protesterne generelt var fredelige, og at demonstranterne råbte 'ingen vold'.

Den politiske ledelse og medierne kritiserede imidlertid demonstranterne for vandalisme på baggrund af episoder med hærværk og destruktiv adfærd foretaget af nogle individer. Militærpolitiets voldelige reaktion blev filmet af en uafhængig journalist, og filmklippet blev lagt ud på facebook, en fremgangsmåde som anvendes af gruppen N.I.N.J.A., der står for en uafhængig og kritisk journalistik i forhold til de førende medier.

\section{Retten til at demonstrere}

Den overdrevne brug af voldelige magtmidler mod fredelige demonstranter og dokumentationen heraf udløste protestbølgen i Brasilien.

Protesterne var i begyndelsen specielt centreret i São Paulo og Rio de Janeiro, men spredte sig hurtigt til de øvrige delstats-hovedstæder og derpå til en lang række større byer over hele landet og toppede den 20. juni, hvor der blev demonstreret og protesteret i over 100 byer med deltagelse af omtrent halvanden million demonstranter.

Protesterne var udtryk for demon- stranternes forsvar af retten til fredelige demonstrationer i et demokratisk Brasilien og rettede sig samtidig mod en bred vifte af forhold, som de protesterende var utilfredse med, og altså ikke bare imod politikernes, mediernes og militærpolitiets håndtering af protesterne.

Desuden var protesterne en reaktion på tilbagetrækningen af prisstigningen på busbilletter i São Paulo, der den 19. juni var blevet annonceret. Under den begivenhed, hvor annonceringen fandt sted, havde der været optrin, hvor individer for protestbevægelsen havde angrebet personer aktive i politiske partier, der havde været til stede for at fejre successen med de tilbagetrukne prisstigninger.

Disse optrin var udtryk for en udbredt skepsis over for de politiske partier og det politiske system blandt de demonstrerende, som har kunnet aflæses på nogle af de bannere, demonstranter har taget med på gaden under protesterne. Eksempler er bannere med påskriften "intet politisk parti repræsenterer mig”, "folket har ikke brug for politiske partier".

\section{Hvem var demonstranterne?}

Under protestbølgen den 20. juni var et meget udbredt slogan på bannerne: "det handler ikke bare om 50 ører”, mens et andet slogan lød "kæmpen er vågnet", hvilket skulle forstås som, at det brasilianske folk 
var vågnet op fra sin passive accept og nu var gået på gaden for at opnå forandringer. Men hvem var det så, der demonstrerede, og hvad ville de opnå? Dette spørgsmål blev særdeles påtrængende for regeringen og andre politiske instanser som delstatsregeringer og bystyrer, da Brasilien den 20. juni vågnede op til den største massedemonstration i Brasiliens historie.

Der har været forskellige bud på, hvem demonstranterne var. Den mest udbredte opfattelse er nok, at der var tale om masseprotester, og at det altså var det brasilianske folk eller masserne, der protesterede og, at der således ikke var tale om et fænomen, der først og fremmest havde rod på den politiske venstre- eller højrefløj, men nærmere i en bred folkelig utilfredshed, der var mere eller mindre diffus.

Samtidig var det først og fremmest unge mennesker i de større byer, der tegnede protesterne, og de fleste vurderinger går på, at langt de fleste af disse tilhørte middelklassen. Der er dog også analytikere, der peger på, at man skal være opmærksom på, at der ikke er tale om én samlet protestbevægelse, men om flere og til tider modsatrettede tendenser blandt demonstranterne i relation til deres indplacering på en skala fra det politiske venstre til det politiske højre.

Andre peger på, at arbejderklassen og bondestanden og de jordløse bønder ikke deltog i protesterne, selvom dette ikke nødvendigvis indikerer uenighed i protesternes substans.

Hvad angår spørgsmålet om, hvad demonstranterne ville opnå, og hvad de demonstrerede imod, er der flere forskellige opfattelser. Den mest udbredte opfattelse er, at der var tale om en meget diffus dagsorden fra demonstranterne, og at der til tider var deciderede selvmodsigelser, hvilket både kunne skyldes fraværet af ledelse, men også forskellige politiske ståsteder og dagsordener.

\section{To hovedtematikker}

Den ene tematik var kravet om flere sociale rettigheder eller i det mindste forbedringer af den offentlige service med hovedvægt på offentlig uddannelse, offentligt sundhedssystem og offentlig transport samt andre lignende områder.

I relation til denne tematik var spørgsmålet om politiske prioriteringer mellem forskellige offentlige investeringer og udgiftsposter centralt i protesterne. Især kritiseredes de enorme udgifter til at bygge nye eller forbedre stadioner til VM i fodbold og regeringens alt for imødekommende politik over for FIFA. Mange af disse penge kunne have været brugt bedre på den brede befolkning gennem forbedringer inden for offentlig uddannelse eller det offentlige sundhedssystem.

Hvem vil have stadioner som i de 
rige lande og hospitaler som i fattige lande, lød et typisk retorisk spørgsmål. En anden kritik relateret til dette hovedtema var kritikken af, at det høje skattetryk, som den brasilianske middelklasse mødes med, ikke modsvares af acceptable velfærdsgoder, hvorfor middelklassen typisk har deres børn i private skoler, ligesom de har private sundhedsforsikringer, da det offentlige sundhedssystem er for ringe.

En økonom har fanget denne problemstilling i begrebet 'Ingana'. De første bogstaver hentyder til England og de sidste til Ghana, og ideen er, at Brasilien kendetegnes ved et (højt) skattetryk som i England og et offentligt sundhedssystem og uddannelsessystem så ringe som Ghanas.

Begrebet er samtidig et spil på ord, da det udtales på samme måde som det portugisiske ord for at snyde. Med andre ord bliver den brede befolkning snydt for sine sociale rettigheder, men betaler skatter i dyre domme, ofte til formål, der kommer de økonomiske og politiske eliter til gode, eksempelvis gennem politikernes enorme lønninger og mange frynsegoder.

Hovedpointen for denne type kritik er, at den brasilianske samfundsorden er socialt uretfærdig, en kritik der minder meget om den amerikanske sociale bevægelse 'Occupy Wallstreet', der tematiserer, at den rigeste procent af amerikanerne har helt urimelige privilegier i forhold til de øvrige 99 pct., som sammenfattes i deres slogan "vi er de 99 pct."

\section{Korruption}

Den anden tematik går på etiske problemstillinger med særligt fokus på korruption og straffrihed i det politiske system, men også mere overordnet om det politiske systems manglende repræsentativitet og den overdrevne indflydelse til økonomisk magtfulde grupper og deres lobbyister, som bevirker, at det politiske system inklusive regeringen $i$ for høj grad tilgodeser private økonomiske interessegrupperinger.

Her er ideen, at de økonomiske og politiske eliter er for sammenspiste og derved bidrager til en uretfærdig samfundsorden enten gennem direkte korruption eller gennem netværksrelationer og favorisering af eliterne. Et godt eksempel på dette kunne være det private busselskab i São Paulo, der står for den lokale transport, der i brugernes øjne leverer en dårlig og utidssvarende løsning, er for langsom og tidsrøvende og alt for dyr. Et andet eksempel var det ekstravagant dyre show, med hvilket fodboldturneringen Confederation's Cup blev skudt i gang midt i juni måned. Her brugte Rio millioner, der i vidt omfang kom mega tv-stationen Rede Globo til gode.

Confederation's Cup blev en kærkommen lejlighed og scene for protesterne. For det første var omverde- 
nens øjne rettet mod Brasilien under denne store sportsbegivenhed, og for det andet kunne protester omkring de stadioner, hvor kampene blev afviklet, tematisere de forkerte politiske prioriteringer af borgernes skattepenge. At flere stadionbyggerier blev væsentligt dyrere end først planlagt, gav naturligvis også anledning til kritik af uregelmæssigheder, altså korruption, i forbindelse med disse anlægsarbejder.

Protesternes fokus kan altså langt hen ad vejen sammenfattes til for det første at være fokuseret på krav om flere rettigheder til den brede befolkning: Altså en udvidelse og forbedring af det sociale system med målsætningen om at skabe en mere socialt retfærdig samfundsmodel gennem en politik, der havde den brede befolknings interesser for øje frem for en begrænset hovedrig elites interesser.

For det andet var der også fokus på etiske problemstillinger, især omkring politikernes forvaltning af deres embeder. Denne sås som plaget af korruption og usunde netværk mellem politiske og økonomiske eliter.

Ligeledes kritiseredes tendensen til at sikre politikere straffrihed i praksis, og i den sammenhæng var der stort fokus i protesterne på lovforslag 37 , der ville øge muligheden for straffrihed, hvis det blev gennemført. Endvidere påpegede mange bannere den enorme afstand mellem politikernes store lønninger og eksempelvis skolelæreres eller universitetslæreres meget lave lønninger.

\section{Diffust fokus}

Det er et meget udbredt synspunkt, at fokus for protesterne var meget diffust, hvorfor det var svært at se, hvad regeringen kunne gøre for at imødekomme demonstranterne. Et andet synspunkt på venstrefløjen var, at man kunne observere, at demonstranter på den politiske højrefløj koncentrerede deres protester om de etiske spørgsmål, herunder lovforslag 37 og korruption, og ikke havde fokus på udbredelsen af sociale rettigheder, som i særlig grad prioriteredes af demonstranter på venstrefløjen.

Venstrefløjs-intellektuelle observatører var i den sammenhæng bekymrede for, at højrefløjens dagsorden skulle blive brugt mod den siddende regering. Flere bekymrede sig om, at der var en fare for, at protesterne kunne føre til et institutionelt tilbageslag, altså at konsekvensen af protesterne med deres negative holdning til formelle politiske institutioner såsom politiske partier og deres kritik af det politiske system i sin helhed og ikke blot af regeringen og venstrefløjen kunne føre til genindførslen af et autoritært politisk system.

Fra denne synsvinkel mødes især de venstreorienterede demonstranter af en skarp kritik for ideen om 
de politiske partiers manglende repræsentativitet med den deraf følgende forkastelse af politiske partier og slogans som "fædrelandet er mit eneste parti”.

Fra dette synspunkt var det decideret farligt for det demokratiske system, at protesterne tog form som en slags masseprotester, og at der blandt demonstranter var tendens til at håne og fordrive de demonstrerende, der mødte op under et partis faner.

Den spanske sociolog Manuel Castells, der er specialist i sociale bevægelser i den digitale tidsalder, og som tilfældigvis var i Brasilien under protesterne, var dog lodret uenig i denne kritik. Han udtalte i et interview, at den spontane natur ved demonstrationerne skulle ses som en fejring af friheden og var udtryk for et dybt politisk engagement blandt de unge studerende, og at det ikke var en svaghed, men en styrke, at de gav udtryk for deres frustrationer i lederløse demonstrationer.

\section{Middelklassen frustration}

Hans position stemmer overens med de observatører, der så demonstrationerne som et sundhedstegn og som udtryk for det brasilianske samfunds demokratisering og for et voksende politisk engagement, der lovede godt for fremtiden og bestemt ikke betød en øget risiko for et autoritært tilbagefald, snarere tværtimod.
Man kan langt hen ad vejen se demonstrationerne som udtryk for en voksende frustration blandt middelklassen i de brasilianske byer i et land, der er blevet mere og mere urbaniseret.

Frustrationen kan siges både at rette sig mod en utilstrækkelig udbygning af socialstaten med dertil hørende borgerlige rettigheder til offentligt finansieret kvalitetsservices og mod korruption og elitære netværk, der fører til politiske beslutninger, der er i eliternes private interesser frem for i den brede folkelige interesse, som burde varetages af det politiske system.

Denne frustration forværredes af afmatningen i den økonomiske vækst og en voksende inflation, der ramte brede befolkningsgruppers levestandard. Dette betød også forværrede fremtidsudsigter for de unge, der var på vej ud på et arbejdsmarked, der for manges vedkommende ikke ville kunne opsuge dem i kvalitetsjob.

Middelklassens vækst og voksende forventninger, måske især blandt unge, var derfor af betydning for den politiske vækkelse i Brasilien. På denne baggrund kan man tale om, at et hovedbudskab fra demonstranterne var deres følelse af en repræsentationskrise. Det politiske system opfattedes ikke som repræsentativt.

Det er svært at vurdere, hvor udbredt denne holdning er i Brasilien. Mange analytikere af den politiske situation har argumenteret for, at 
flertallet i befolkningen var enige med demonstranterne, der for de flestes vedkommende var unge byboer fra middelklassen.

På den anden side var regeringens popularitet til trods for et stort fald i meningsmålinger foretaget under protesterne tilsyneladende på et pænt niveau, hvilket uden tvivl kan tilskrives det forhold, at mange brasilianere har oplevet forbedrede levekår under den nuværende PT-ledede regering.

\section{En rådvild præsident}

Præsident Dilma og hendes parti PT virkede rådvild og desorienteret, da de største protester i Brasiliens historie udfoldede sig den 20. juni, hvor hun havde indkaldt til krisemøde i regeringens inderkreds.

Man ventede, at hun ville komme med en reaktion på protestbølgen den 20. juni om aftenen, men hendes reaktion kom først dagen efter i en tale bragt i tv. I denne tale udtrykte hun, at hun og regeringen havde hørt stemmen fra gaderne, og at denne var en legitim stemme, der var vigtig i den demokratiske proces.

Hun uddybede, at hun ville kalde til dialog blandt regeringsmedlemmer, delstatsguvernører og andre politiske ledere samt repræsentanter fra de sociale bevægelser for at finde frem til fælles løsninger med henblik på at imødekomme krav fra demonstranterne.

Hun skitserede endvidere, at der ifølge hendes fortolkning af demonstrationerne og de rammer, som den brasilianske virkelighed satte om regeringens svar, var behov for at prioritere en indsats på fem områder.

Heraf vedrørte de tre sociale rettigheder inden for uddannelse, sundhed og transport. Der skulle sættes væsentligt flere penge af til investeringer på dette område.

Den fjerde prioritet var at sikre en politik, der sørgede for at bevare budgetansvarligheden, der anses som en nødvendighed for at sikre den makroøkonomiske stabilitet, og som regeringen og en bred vifte af $\varnothing$ konomiske analytikere ser som en central komponent i den udviklingssucces, Brasilien har haft i perioden med PT-ledede regeringer siden 2003. Den fjerde prioritet skulle således sætte 'ansvarlige' grænser for væksten i investeringer inden for de første tre prioriteter for at undgå at øgede investeringer skulle føre landet ud i økonomisk ustabilitet og voksende inflation. Den femte og sidste prioritet for præsidenten var at gennemføre en større reform af det politiske system i Brasilien.

\section{Forslag til reform}

Præsidenten nævnte i denne sammenhæng, at det ville være ønskværdigt, at individer uden for det politiske system udviklede et forslag til en politisk reform, der så skulle vedtages af en konstituerende forsamling. Humlen i forslaget var, at præsi- 
denten for at sikre en dyb politisk reform, ønskede omgå det etablerede politiske system og altså parlamentet, da det sås som domineret af traditionelle politikere, der ikke ville være indstillet på en reform, der kunne ramme deres egne muligheder.

Reaktionen på præsident Dilmas tale var meget varieret. En analytiker beskrev den som patetisk ud fra det argument, at præsidenten ville omgå den aftale, som den politiske koalition hendes egen regering var baseret på, havde indgået.

Castells hyldede Dilma som den eneste ægte demokratiske præsident blandt de ledere, der i løbet af de sidste få år havde stået over for omfattende folkelige, sociale protester. Hans argument var, at hun eksplicit pointerede de demonstrerendes ret til at demonstrere og viste sig imødekommende over for deres krav. Den eneste måde at opnå den ønskede politiske reform, der kunne løsne op for den hårdknude, som det politiske system i Brasilien udgjorde, var at omgå traditionelle politikere med deres tætte tilknytning til økonomiske eliter.

Imidlertid var han overbevist om, at Dilma ikke ville opnå den politiske opbakning til sit forehavende, da hun til syvende og sidst var afhængig af det etablerede politiske systems opbakning til reformen, som han anså som fuldstændig usandsynlig. Imidlertid pegede dialogtilgangen og imødekommenhe- den i forhold til de sociale rettigheder, der var centrale i protesterne, $\mathrm{i}$ retning af, at der var gode muligheder for, at de protesterende og det etablerede politiske system kunne møde hinanden og finde løsninger. Ikke mindst fordi regeringen gerne så forbedringer inden for sociale rettigheder inden for de begrænsninger, som budgetterne satte. En voksende prioritering af disse områder kunne altså sikre positive resultater. Konkret foreslog Dilma, at en stor del af ressourcerne til forbedringerne inden for uddannelse og sundhed skulle komme fra statens oliefond.

Den 27. juni spilledes finalen i Confederation's Cup på Maracanã stadion i Rio uden præsidentens tilstedeværelse. I dagene imellem Dilmas tale og finalekampen mellem Brasilien og Spanien, som Brasilien i $\varnothing$ vrigt vandt, havde Dilma konkretiseret nogle af sine forslag til at imødekomme demonstranternes krav, og lovforslag 37 var blevet stemt ned i parlamentet.

Efter fodboldturneringens afslutning svandt protesternes omfang og intensitet kraftigt ind, men flere af de grupper, der opstod og deltog $\mathrm{i}$ protesterne, lever videre og sender dagligt deres budskaber ud på facebook, bl.a. med anklager om korruption, kritik af Rede Globo, lister over de rigeste brasilianere og så videre.

Regeringens popularitet er atter steget som tidligere nævnt. 


\section{Hvad bliver konsekvensen?}

Hvad kan vi forvente os, at konsekvensen af protesterne bliver for den politiske og økonomiske udvikling? Det er svært at sige. Økonomen Marcelo de Paiva Abreu argumenterede i slutningen af juni efter Dilmas tale for, at en cocktail af diffuse protester og politisk rådvildhed omkring, hvordan man fra regeringens side skal reagere på dem, er farlig, fordi sådan en situation nærmest opfordrer demonstranterne til direkte aktioner, og at man derfor kan forvente fortsatte protester.

Problemet med dette er faren for, at det politiske systems svar på protesterne ikke bliver økonomisk rationel, og at en konsekvens derfor let kan blive uansvarlige makroøkonomiske politikker, der vil føre til øget inflation og forværre en allerede problematisk økonomisk situation. Det ville være bedre, hvis det politiske system fik arbejdsro til at udvikle økonomisk set rationelle politikker.

Altså ser denne analytiker en fare for fortsatte demonstrationer og en forværring af den økonomiske situation.

Man kan også sige, at dette tegner et billede af en relativt succesrig økonomisk udvikling, der var under opbremsning i 2013, og at de sociale og politiske protester samt de politiske svar på disse risikerer at medføre en ond spiral med voksende økonomisk og politisk ustabilitet, der ikke vil være befordrende for imødekom- melsen af demonstranternes krav.

En anden mulighed, der virker mere sandsynlig er, som Castells siger, at det etablerede politiske system og demonstranterne vil kunne finde hinanden igen grundet præsidentens og regeringens imødekommenhed over for demonstranternes kritik og krav.

Dette betyder dog ikke, efter min vurdering, at protesterne vil ophøre. Mange grupper og individer har fået smag for engagement i den politiske proces, og man vil derfor fortsat opleve en stor opmærksomhed omkring korruption, straf af korruption samt kritik af en uretfærdig samfundsorden og kravet om forbedringer af forskellig art for at forbedre den eksisterende samfundsorden.

\section{Demokratiseringsproces}

Generelt set virker det sandsynligt, at kommende protester ikke vil nå det samme omfang som i juni med mindre, der kommer en særlig anledning til det, som man så med militærpolitiets overdrevent hårdhændede fremfærd over for demonstranterne, der protesterede mod de øgede priser på lokal bustransport i São Paulo.

Protesterne i Brasilien kan ses som et led i Brasiliens demokratiseringsproces, der understøttes af den store udvidelse af middelklassen, der typisk er væsentlig for demokratiseringsprocesser, og som et udtryk 
for en voksende folkelig forventning til ustraffet at kunne deltage aktivt i den politiske proces, også når dette sker gennem folkelige protester.

Det er straks sværere at vurdere, hvad det mest sandsynlige scenarie for økonomien vil være.

Umiddelbart kan man udmærket forestille sig, at regeringen formår at ændre sine udgiftsprioriteter i retning af uddannelse, sundhed og transport, og at dette kan kombineres med budgetansvarlighed.

Det betyder ikke, at denne politik nødvendigvis er den bedste for landet. Man kunne eksempelvis argumentere for, at andre formål såsom øgede investeringer i transportinfrastrukturen inde i landet, altså ikke den kollektive transport i byerne, kunne have endnu mere positive samfundsøkonomiske effekter.

Under alle omstændigheder er det udfordrende at prioritere 'rigtigt' fra en økonomisk synsvinkel, ligesom man må forvente, at den stærke opinion fra de magtfulde middelklasser i byerne vil have en stor politisk tyngde og vil spille væsentligt ind på samtlige politiske partiers valgplatforme op til præsidentvalget i 2014.

Endeligt står Brasilien over for store makroøkonomiske udfordringer fra et stort og voksende underskud over for udlandet på betalingsbalancens løbende poster og fra tendensen til langsom økonomisk vækst og en udfordrende kontekst på handelsområdet.

Disse problemstillinger kan denne analyse dog ikke gå dybere ind i, men det står fast, at en eventuel forværring i den økonomiske udvikling i den nærmeste fremtid ikke nødvendigvis vil være forårsaget af protestbølgen, der startede i Brasilien i juni 2013.

Steen Fryba Christensen er lektor ved Institut for Kultur og Globale Studier, Aalborg Universitet. 